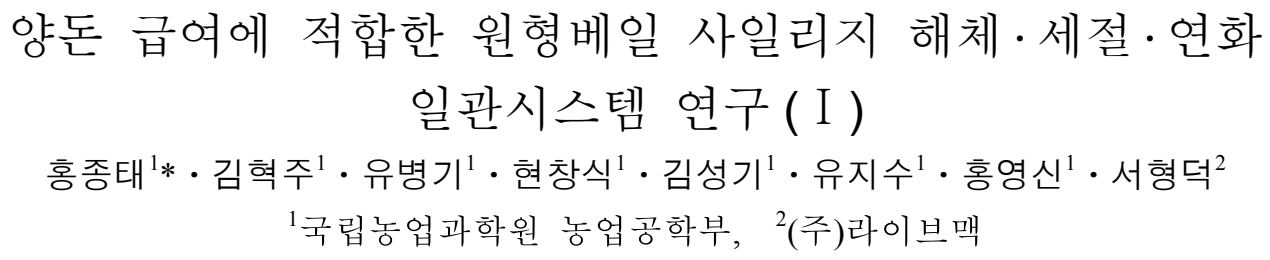

\title{
A Study on the Integrated Unrolling, Cutting, and Softening System of Round Bale Silage for Pig Feeding ( I )
} Jong-tae Hong ${ }^{1}$, Hyuck-joo Kim¹, Byeong-kee $\mathrm{Yu}^{1}$, Chang-sig Hyun ${ }^{1}$, Sung-kee Kim ${ }^{1}$, Ji-soo Yoo', Young-sin Hong ${ }^{1}$, Hung-dug Seo ${ }^{2}$

${ }^{1}$ Agricultural Engineering Department, National Academy of Agricultural Science, RDA, Suwon 441-707, Korea, ${ }^{2}$ Yongin Office, Livemac Co., Ltd, Yongin 446-599, Korea

\begin{abstract}
Currently, there was no producing system of TMR for pig feeding in Korea. In this study, we examined unrolling, cutting, and softening for the round bale silage. We designed and developed the prototype system of round bale silage for pig feeding. Unroll method were lower chain conveying and upper belt conveying which includes an hydraulic vertical fodder knife. Gathering and cutting method were rotating auger and flywheel which have 10 cutters, input roller of 280 $\mathrm{rpm}$, and cutter rotating speed of $1,750 \mathrm{rpm}$. Softening device was rotating hammer in inclined cylinder adjustable to $25^{\circ}$ and rotating speed up to $1,300 \mathrm{rpm}$. The prototype system was integrated working for unrolling, cutting, and softening. We found that when the round bale silage in unrolling apparatus cut length of $20 \mathrm{~cm}$ to input cutting apparatus, the cutting performance was well in continuous working up to input rate of $1,000 \mathrm{~kg} / \mathrm{h}$, the softening apparatus was working well.
\end{abstract}

(Key words : Pig feeding, TMR, Round bale, Integrated unrolling-cutting-softening system)

서 론

한-EU·한미 FTA 등 대비 돼지 생산성 향상과 사료비 절감이 절실하다. 현재 국내 양돈농가의 생산비중 사료비용이 차지하는 비율이 전체의 약 $60 \sim 70 \%$ 로 가장 큰 비중을 차지하고 있어 생산비를 낮추기 위한 사료비 절감이 절실히 필요하다. 특히 돼지는 주로
배합사료에 의하여 사육이 이루어지는데, 국 내의 경우 2009 년 기준 연간 4,280 천 톤에 달 하는 양돈용 배합사료 원료인 곡물사료의 대 부분을 수입에 의존하고 있는 실정이다. 수 입되고 있는 배합사료 주요원료 가격을 한국 사료협회에서 관세청 자료를 기준으로 분석 한 결과 2005년 톤당 151달러에서 2013년 상 반기 331달러로 두 배 이상 올랐다. 이는 배

Corresponding author : Jong-tae Hong, National Academy of Agricultural Science, RDA, Suwon 441-707, Korea. Tel: +82-31-290-1864. E-mail : hongjt@korea.kr

2013년 8월 23일 투고, 2013년 9월 10일 심사완료, 2013년 9월 20일 게재확정 
합사료의 주요원료를 생산 수출하는 곡물생 산국에서 토지, 종자, 비료대금 등 곡물생산 비용 증가, 이상기후로 인한 공급 감소, 중 국, 인도 등의 신수요 증가와 외환시장에서 환율 변동 등에 원인이 있는 것으로 전문가 들은 분석하고 있다.

최근 사료원료 가격이 급등함에 따라 사료 비 절감을 위하여 조사료 및 농업부산물 등 을 발효시켜 돼지에 급여하는 연구가 이뤄지 고 있다. Cho (2009)는 양돈용 청보리 발효사 료 제조 및 이용 기술 연구결과에 의하면 배 합사료에 원형베일 사일리지를 $3 \mathrm{~cm}$ 이하로 분쇄한 사일리지를 $30 \%$ 포함한 풀 발효사료 를 임신돈에 급이 시 일반사료를 먹인 돼지 에 비해 새끼돼지 1마리를 더 생산하고 새끼 돼지의 생시체중도 $10 \%$ 높아져 생산성이 향 상되었다. 또한, 풀 발효사료 급여 후 분변에 서 미생물변화를 확인한 결과 대장균이 $25 \%$ 감소하고 유산균이 $18 \%$ 증가해 장내환경개 선에 영향을 미친 것으로 나타났으며, 혈액 분석결과 면역력 증진 효과가 확인되었으며, 이외에도 변비해소, 분뇨의 악취저감, 임신돈 의 포만감 충족에 의한 스트레스 저감 효과 등이 있는 것으로 보고되고 있다.

원형베일 세절연화 기계기술과 관련한 국 내외 기술개발 현황은 한우와 젖소용 위주의 원형베일 해체, 절단, 연화관련 연구가 주류 를 이루고 있으며, 양돈용은 아직 시작단계 에 있다. 국내에서 수행한 원형베일 해체, 세 절, 연화 관련 연구로 Park et al.(2000)은 젖 소와 한우에 이용되는 거친 조사료원인 볏짚 의 사료가치 향상을 위해 해머형의 칼날 회 전에 의한 세절과 동시에 스크린 망에 타격 되어 연질화 되도록 시험한 결과 날 회전수 $1,780 \mathrm{rpm}$, 스크린 규격은 $\varnothing 100 \mathrm{~mm}$ 에서 스크 린에 막힘없이 연질화가 잘되는 것으로 보고 하였다. $\mathrm{Yu}$ et al. (2002)은 TMR 제조기에 원 형베일을 잘게 세절하여 공급할 수 있도록 1 차 칼날부착 드럼회전식 절단장치와 2 차 플
라이휠 날 회전식 절단장치를 조합한 볏짚 원형베일 초퍼를 개발 시험한 결과 처리성능 은 $964 \mathrm{~kg} / \mathrm{h}$, 평균 절단길이는 $13.9 \mathrm{~cm}$ 인 것으 로 나타났다. Hong et al. (2005)은 젖소 및 한 우용 원형베일을 한 번에 세절과 동시에 급 여 할 수 있도록 절단날이 부착된 원통형의 회전축을 회전시켜 고정날과 교차하면서 공 급된 원형베일을 절단하는 방식의 세절급여 기를 고안하여 시험결과 절단된 볏짚의 길이 는 $10 \sim 15 \mathrm{~cm}$ 분포가 $80 \%$ 로 나타났다. 국외기 술 개발현황으로는 M. Zhang et al. (2003)은 프레일날 회전에 의한 절단 동시 회전차를 준 상하롤러 사이를 통과시켜 연화하는 원리 를 이용한 옥수수 사일리지 수확기의 설계 및 평가 결과 옥수수 세절하는데 소요되는 총 비에너지는 $4.5 \sim 10.6 \mathrm{kWh} / \mathrm{ton}-\mathrm{DM}$ 정도였 으며, 세절과 동시에 연화한 옥수수는 단순 세절만 한 옥수수보다 압축밀도가 높은 것으 로 나타났다.

현재 국내에는 반추위를 가진 한우나 젖소 의 사양에 맞도록 조사료 세절길이 분포가 $10 \sim 15 \mathrm{~cm}$ 정도로 제조하는 TMR 사료조제 시스템은 연구 개발되어 보급되고 있으나, 돼지에 적용 가능한 $\mathrm{TMR}$ 조제시스템은 아 직 국내외에 없어 기술개발이 절실히 요구되 고 있다. 특히 양돈 급이에 적합한 $\mathrm{TMR}$ 조 제시스템 연구개발을 위해서는 우선 Italian Ray Grass (IRG), 청보리 등의 원형베일을 해 체하여 $3 \mathrm{~cm}$ 이하로 세절하고, 이어서 $\mathrm{TMR}$ 재료의 혼합성능 향상과 돼지의 소화를 돕기 위해서 연화작용을 가하여 배출하는 시스템 개발이 필요하다.

따라서 본 연구에서는 양돈 급여에 적합한 원형베일 해체, 세절, 연화 일관시스템 개발 을 위해 원형베일 사일리지 종류별 물리적 특성을 분석하고, 원형베일 해체, 절단, 연화 요인 구명결과를 토대로 시작기를 설계 제작 하여 작업조건 구명시험을 수행하였다. 


\section{재료 및 방법}

\section{1. 원형베일 사일리지 종류별 물성조사}

원형베일 사일리지 세절시스템 개발을 위 한 기초자료를 얻고자 Italian Ray Grass (IRG), 청보리, 볏짚 등 원형베일 사일리지 종류별 로 공시재료 직경, 절단특성, 수분함량, 베일 규격 $125 \times 125 \mathrm{~cm}$ 인 원형베일의 무게 등을 조사하였다. 절단특성을 알아보기 위해 사일 리지 종류별 줄기의 절단강도 측정실험은

Texture analyser (Model : FUTURE-TECH, JP/ $\mathrm{ARS})$ 를 이용하였고, 공시 절단날은 두께 3 $\mathrm{mm}$, 날폭 $60 \mathrm{~mm}$, 날 경사각 $20^{\circ}$ 의 편날을 사용하여 절단속도 $10 \mathrm{~mm} / \mathrm{s}$ 의 속도로 절단 시 최대절단력, 최대절단력까지 도달거리를 조사하였다.

2. 원형베일 해체, 절단, 연화 요인시험

원형베일 사일리지를 해체와 동시에 잘게 세절한 후 연화시킬 수 있는 시스템 설계요 인 구명을 위해 요인시험 장치를 Fig. 1과 같 이 제작하여 공시하였고, 공시재료로 베일규 격 $125 \times 125 \mathrm{~cm}$ 인 $\mathrm{IRG}$ 를 공시하여 원형베일 해체시험, 절단시험, 연화시험을 실시하였다. 원형베일 해체 요인구명을 위하여 1차 유압 모터용량 $250 \mathrm{cc} /$ 분, 이송속도 $0 \sim 10 \mathrm{~cm} / \mathrm{s}$, 이송 각도 $35^{\circ}$, 이송체인 3 열, 이송체인 러그높이 $0 \sim 10 \mathrm{~cm}$ 조절 가능한 체인컨베어식 해체 시
험 장치를 이용 시험결과 이송체인 러그 높 이 $5 \mathrm{~cm}$ 정도에서 배출이 잘되었으나, 해체 한 조사료를 절단기에 연속투입 시 막힘과 베일절단유무에 따른 적응성, 베일잔량처리 등의 문제가 있었다. 이에 원형베일 해체와 동시에 커팅작업이 가능하도록 해체방식은 체인컨베어식으로 이송체인 4열, 러그높이 5 $\mathrm{cm}$, 이송각도 $15^{\circ}$ 로 하였고, 커팅방식은 상하 구동 작두날식으로 시험장치를 제작하여 체 인컨베이어 열수, 이송각도 및 상부 잔량처 리장치 부착형태, 베일 절단유무별 (미절단 베일, $30 \mathrm{~cm}$ 절단 베일)로 해체정도, 잔량처 리 및 절단기 작업가능성 등을 조사하였다.

원형베일을 해체 후 유입되는 사일리지 절 단 요인구명을 위하여 배일 해체기에서 해체 된 사일리지를 집속과 동시에 절단 할 수 있 도록 하였으며, 집속방식은 오거회전식, 절단 방식은 플라이 휠형으로 절단드럼 직경과 날 길이 $\varnothing 640 \times 278 \mathrm{~mm}$, 절단 크기조절은 유입 로러 회전수 조정과 절단 날 5 10개를 탈부 착 하여 조절 할 수 있는 절단 시험장치를 이용하여 칼날개수, 절단날 및 유입롤러 회 전수별 세절길이 분포, $30 \mathrm{~mm}$ 이내 비율, 평 균 절단길이 등을 조사하였다.

잘게 세절된 사일리지의 연화 요인구명을 위하여 1 차 해머회전 + 스크린식 연화 시험장 치를 제작하여 스크린 규격별로 시험결과 연 화정도는 양호하였으나, 처리능률이 낮고 스 크린에 막힘 현상이 있었다. 이에 막힘없이 연속작업이 가능토록 제작한 경사원통 해머

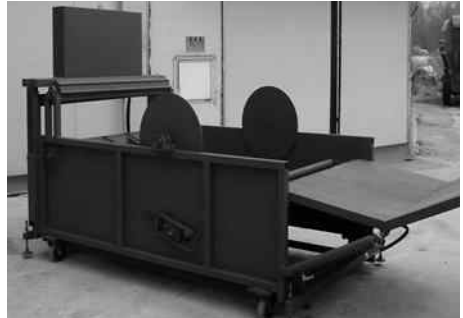

Unrolling device

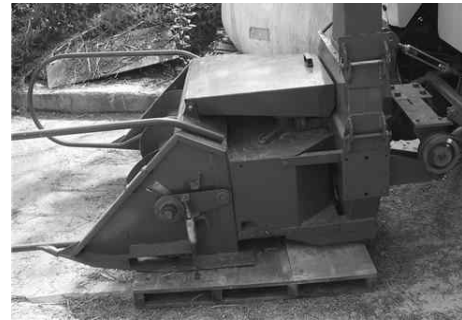

Cutting device

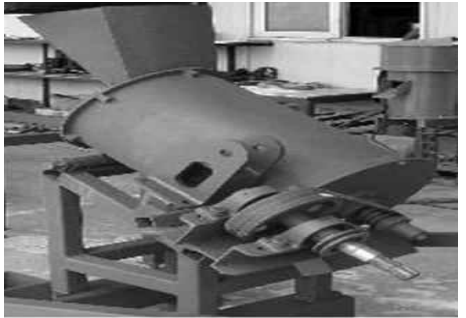

Softening device

Fig. 1. The experimental unrolling, cutting, softening devices for round bale silage. 
회전식 연화 시험장치는 해머 두께와 길이 $6 \mathrm{t} \times 150 \mathrm{~mm}$, 개수 50 개, 해머 선단과 원통사 이 간격은 $4 \mathrm{~mm}$, 경사원통 각도 조절은 최대 $30^{\circ}$ 로서 연화 요인시험은 경사원통 각도별, 해머 회전수별로 세절길이분포, $30 \mathrm{~mm}$ 이내 비율 등을 조사하였다.

\section{3. 시작기 설계제작 및 작업조건 구명시험}

\section{(1) 시작기 설계제작}

설계요인 구명시험 결과를 토대로 원형베 일 사일리지 해체, 세절, 연화 일관 시스템은 베일을 해체와 동시에 커팅하여 절단기에 보 내면 $3 \mathrm{~cm}$ 이하로 잘게 세절한 후 경사원통 내 해머회전에 의해 연화시킬 수 있도록 Fig. 2 와 같이 시작기를 설계제작 하였다. 원형베 일 해체장치는 원형베일 해체, 계량, 커팅, 배출 일관형으로 해체방식은 베일절단 유무 에 관계없이 처리가 가능하고, 해체두께를 일정하게 유지하며 잔량처리가 용이하도록 하부에는 체인컨베이어 (체인 4열, 러그높이 $5 \mathrm{~cm}$, 러그간격 $30 \mathrm{~cm}$ ), 상부에는 벨트컨베이 어를 부착하였고, 체인과 벨트컨베이어의 회 전비는 $1: 1.2$ 로 하였다. 계량은 로드셀 (400 $\mathrm{kg}, 4$ 조)을 부착하여 베일해체 중 베일 무게 를 측정할 수 있도록 하였고, 커팅방식은 상 하구동 작두날식으로 작동거리 $40 \mathrm{~cm}$, 동력 은 전기모터에 의한 유압구동방식으로서 베 일은 최대 $130 \mathrm{~cm}$ 까지 적용가능토록 제작하
였다. 절단장치는 해체베일 집속, 절단, 배출 일관형으로 집속방식은 오거회전식으로 오거 직경 $430 \mathrm{~mm}$, 오거피치 $425 \mathrm{~mm}$, 축경 224 $\mathrm{mm}$, 집속폭 $120 \mathrm{~cm}$, 절단방식은 플라이 휠형 으로 절단날 드럼직경 $\varnothing 640 \mathrm{~mm}$, 날 길이 $278 \mathrm{~mm}$, 날 개수 10 개를 부착하였고, 배출방 식은 막힘이 없도록 측면 배출하도록 제작하 였다. 임시저장호퍼 및 연화장치는 절단기에 서 절단된 세절물을 임시호퍼 (용량 : $0.6 \mathrm{~m}^{2}$ ) 에 저장하였다가 벨트컨베이어를 이용 경사 원통형 해머회전식 연화기에 투입 연화 후 배출하도록 되어있으며, 해머두께 및 길이는 $6 \mathrm{t} \times 150 \mathrm{~mm}$, 해머개수 50 개, 경사원통 각도 는 설계요인시험에서 구명된 $25^{\circ}$, 연화성능 향상을 위하여 세절물을 연화기의 중앙에 투 입하던 것을 해머회전 방향 측면에 투입하여 세절물의 유입이 원활하도록 제작하였다. 또 한 세절물과 연화물의 이송은 체인컨베이어 를 이용하여 이송되도록 하였고, 각부 동력 전달은 TMR 배합소 등에서 활용이 용이한 전기모터 및 유압시스템을 이용하여 동력전 달토록 하였다.

\section{(2) 소요동력 측정시스템}

본 시험에서는 해체장치에서 원형베일이 해체와 동시에 커팅되어 절단장치에 투입되 는 투입량의 변동이 있는 조사료를 절단작업 시 실시간 $\mathrm{PTO}$ 축 소요동력을 측정하기 위하 여 동력전달축과 절단장치의 구동축에 정격토
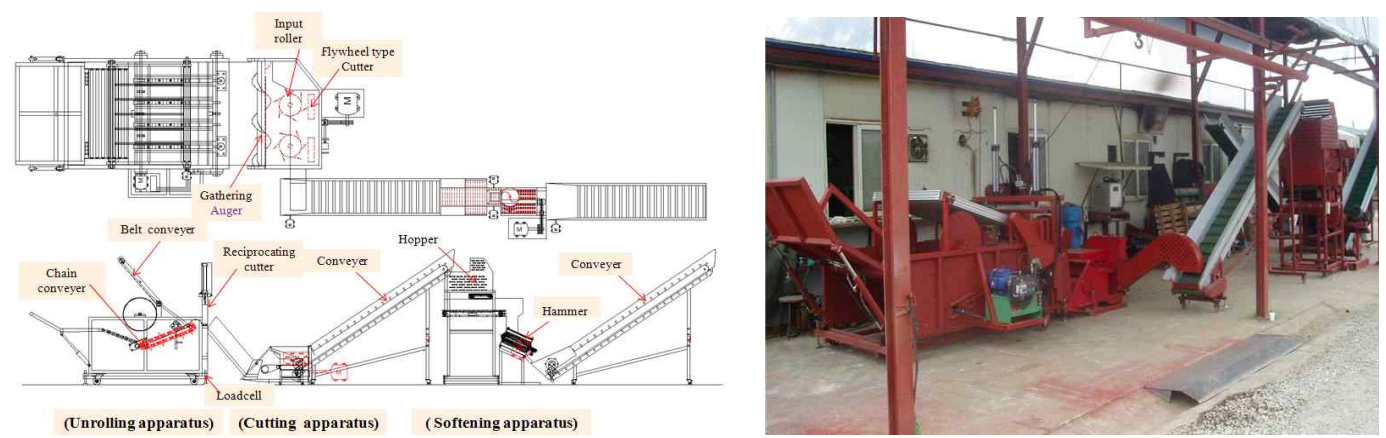

Fig. 2. Schematic diagram \& structure of the protype for round bale silage. 
크가 $1,800 \mathrm{Nm}$ 인 비접촉 회전식 토크미터(영 국 DATUM electronics사, Model: Series420, PTO system)를 사용하여 작업기가 유동상태 에서도 안정성을 확보할 수 있는 floating Type을 적용하였고, 소요동력 측정시스템은 데이터를 저장 및 분석하는 터치페널, 상용 토크가 내장된 PTO 동력전달 축, 시험의 시 작/정지 기능을 위한 트리거 버튼, 테이터 획 득 및 처리장치 등으로 구성하였다. 소요동 력 측정프로그램은 Power KIT 2.7B를 사용하 였고, 소요동력 측정 장치로 획득한 토크 $\left(\mathrm{T}_{\mathrm{p}}\right)$ 및 회전속도 $\left(\mathrm{N}_{\mathrm{p}}\right)$ 데이터는 아래의 식 1 과 같 이 소요동력 계산공식 $(\mathrm{P})$ 을 이용하여 자동으 로 산출되도록 하였다.

$$
P=\frac{2 \pi T_{p} N_{p}}{60,000}
$$

\section{Where;}

P: Power Requirement of PTO (kw)

$$
\begin{aligned}
& \mathrm{T}_{\mathrm{p}} \text { : Toque of PTO shaft }(\mathrm{Nm}) \\
& \mathrm{N}_{\mathrm{p}} \text { : Number of PTO shaft rotation (rpm) }
\end{aligned}
$$

또한, 비교적 소요동력이 적은 베일해체, 연화작업 시 소요되는 모터의 소요동력 측정 시험에는 적산전력계 (보통전력량계, 정밀도 $\pm 2.0 \%, 220 / 380 \mathrm{~V}$ 겸용, $75 \mathrm{rev} / \mathrm{kwh}$ )를 이용하 였으며, 공시한 적산전력계는 $1 \mathrm{kwh}$ 가 소요 되려면 1시간에 원판이 72 회전 하게 된다. 따라서 실제 소요동력 측정을 위해 적산전력 계의 원판이 1 회전하는데 소요되는 시간(초) $\mathrm{h}^{\prime}$ 를 측정하고 여기에 모터의 역률 0.8 로 하 여 아래의 식 2 와 같은 소요동력 계산공식 $\left(\mathrm{P}^{\prime}\right)$ 을 이용 산출하였다.

$$
\mathrm{P}^{\prime}=\frac{3,600}{72 \mathrm{~h}^{\prime}} \times 0.8
$$

(3) 공시재료 및 시험방법

원형베일 사일리지 세절시스템 시작기의 각부 전 - 후 작업연계성을 고려한 마이크로
프로세스 제어를 하기에 앞서 적정작업조건 을 구명하기 위해 베일규격 $125 \times 125 \mathrm{~cm}$ 인 IRG 품종의 원형베일 사일리지를 공시재료 로 하여 시험하였다. 베일해체작업조건 구명 은 해체장치의 이송 및 커팅작업을 on/off 스 위치를 이용 수동으로 작동하면서 커팅길이 $10 \mathrm{~cm}, 20 \mathrm{~cm}, 40 \mathrm{~cm}$ 별로 사일리지 무게, 해 체소요시간 및 소요동력을 조사하였다. 절단 작업조건 구명은 절단장치의 칼날개수 10 개, 절단날 회전수 $1,750 \mathrm{rpm}$, 유입롤러 회전수 $280 \mathrm{rpm}$ 으로 맞춘 상태에서 해체장치에 의해 커팅된 사일리지 길이별로 절단장치에 투입 시 세절길이 분포, $30 \mathrm{~mm}$ 이내 비율, 평균절 단길이, 용적중, 소요동력 및 연속작업 가능 성 등을 조사하였다. 연화작업조건 구명은 연화장치의 경사원통각도 $25^{\circ}$, 해머 날 회전 수 $1,300 \mathrm{rpm}$ 로 맞춘 상태에서 최대 연화능률 및 연속작업 가능성을 보기위해 절단된 사일 리지를 분당 $8.3 \mathrm{~kg}(500 \mathrm{~kg} / \mathrm{h}), \quad 12.5 \mathrm{~kg}(750$ $\mathrm{kg} / \mathrm{h}), \quad 16.7 \mathrm{~kg}(1,000 \mathrm{~kg} / \mathrm{h}), \quad 20.8 \mathrm{~kg}(1,250 \mathrm{~kg} / \mathrm{h})$ 투입 시 연화정도 및 소요동력 등을 조사하 였다.

\section{결과 및 고찰}

\section{1. 원형베일 사일리지 종류별 물리적 특성 분석}

원형베일 사일리지의 절단특성을 알아보기 위해 사일리지 종류별 직경, 최대절단력, 최 대절단력 까지 도달거리, 베일무게 등을 조 사한 결과는 Table 1과 같다. 절단강도 측정 시 일단 지지한 상태에서 절단 날은 두께 3 $\mathrm{mm}$, 날폭 $60 \mathrm{~mm}$, 절단각 $20^{\circ}$ 의 편날을 공시 하여 절단속도 $10 \mathrm{~mm} / \mathrm{s}$ 로 절단 시 최대절단 력은 IRG $133.88 \mathrm{~N}$, 청보리 $36.29 \mathrm{~N}$, 볏짚 $46.65 \mathrm{~N}$ 로 IRG 절단 시 절단력이 가장 높게 나타났으며, 최대 절단력 까지 도달거리는 Fig. 3 와 같이 최초에는 날 끝의 힘이 충분하 
Table 1. Physical properties for various round bale silages.

\begin{tabular}{|c|c|c|c|c|c|c|c|}
\hline \multirow{2}{*}{ Silages } & & \multicolumn{2}{|c|}{$\begin{array}{l}\text { Diameter of stem } \\
\text { silage }(\mathrm{mm})\end{array}$} & \multirow{2}{*}{$\begin{array}{l}\text { Maximum } \\
\text { cutting force } \\
\text { (N) }\end{array}$} & \multirow{2}{*}{$\begin{array}{c}\text { Distance to } \\
\text { maximum cutting } \\
\text { force }(\mathrm{mm})\end{array}$} & \multirow{2}{*}{$\begin{array}{l}\text { Moisture } \\
\text { content } \\
(\%, w . b .)\end{array}$} & \multirow{2}{*}{$\begin{array}{l}\text { Round bale } \\
\text { weight } \\
\text { (kg/roll) }\end{array}$} \\
\hline & & Width & Length & & & & \\
\hline \multirow{2}{*}{ IRG } & Average & 3.06 & 6.42 & 133.88 & 4.30 & 76.8 & 605 \\
\hline & S.D & 1.38 & 0.74 & 71.23 & 1.11 & 1.97 & 5.0 \\
\hline \multirow{2}{*}{ Barley } & Average & 1.51 & 5.47 & 36.28 & 2.58 & 68.3 & 703 \\
\hline & S.D & 0.27 & 0.91 & 5.78 & 0.87 & 1.13 & 12.5 \\
\hline \multirow{2}{*}{ Straw } & Average & 1.82 & 4.12 & 46.65 & 6.03 & 65.7 & 401 \\
\hline & S.D & 0.64 & 1.67 & 12.71 & 0.45 & 1.17 & 43.0 \\
\hline
\end{tabular}

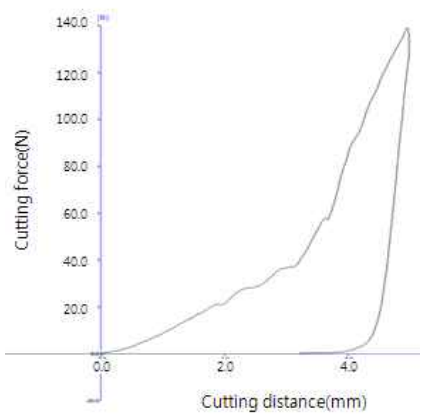

IRG

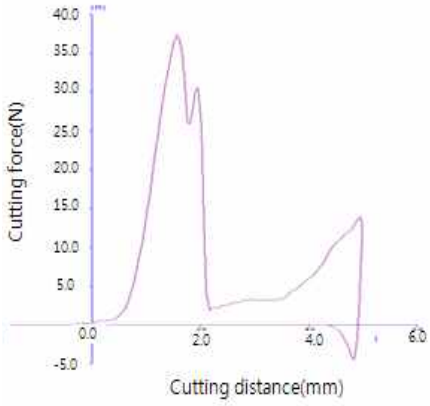

Barley

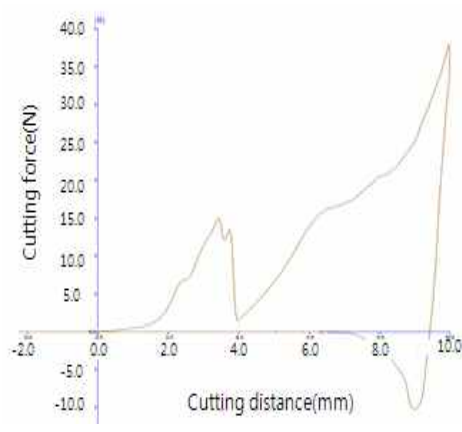

Straw

Fig. 3. The relationship between cutting force and stem cutting distance for silages.

지 못하여 압축 응력이 증가하다가 그 후 줄 기의 초기파괴가 일어난 다음에 부분적으로 는 압축이 계속되고 절단이 일어나면서 IRG 는 평균 $4.30 \mathrm{~mm}$, 청보리는 평균 $2.58 \mathrm{~mm}$, 볏 짚은 평균 $6.03 \mathrm{~mm}$ 에서 최대 절단력까지 도 달하였다가 절단이 계속되어 날 끝이 줄기를 절단함에 따라 힘이 급격히 떨어지는 경향을 보였다. 또한 사일리지 종류별 원형베일 125 $\times 125 \mathrm{~cm} 1$ 롤의 평균무게는 IRG $605 \mathrm{~kg}$, 청보 리 $703 \mathrm{~kg}$, 볏짚 $401 \mathrm{~kg}$ 로 나타났다.

\section{2. 원형베일 해체, 절단, 연화 요인시험}

원형베일 사일리지 세절시스템의 설계조건 구명을 위하여 원형베일 해체, 절단, 연화요 인시험결과는 다음과 같다.
원형베일 해체요인시험은 원형베일 해체와 동시에 커팅작업이 가능하도록 해체시험 장 치를 제작하여 체인컨베이어 열수, 이송각도, 상부 잔량처리장치 부착형태 및 베일 절단유 무별로 해체 요인시험결과 Table 2와 같이 해체방식은 하부에는 체인컨베어식으로서 체 인 4 열, 러그높이 $5 \mathrm{~cm}$, 이송각도 $15^{\circ}$ 로 하고, 상부에는 벨트컨베이어 방식으로서 체인과 밸트컨베이어의 회전속도비 $1: 1.2$ 로 한 경우 베일절단 유무에 관계없이 사용되고, 베일 잔량처리도 되며, 상하작동 작두날이 부착되 어 있어 일정 길이로 커팅하여 절단기에 투 입할 수 있어 절단기에서 막힘없이 연속작업 이 가능한 것으로 판단되었다.

원형베일을 해체 후 유입되는 사일리지 절 단 설계 요인구명을 위하여 집속방식은 오거 
Table 2. Unrolling and residue treating posturer by the different unrolling methods.

\begin{tabular}{|c|c|c|c|c|c|}
\hline \multicolumn{3}{|c|}{ Types } & 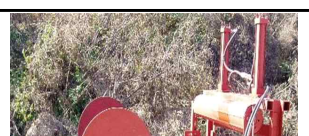 & 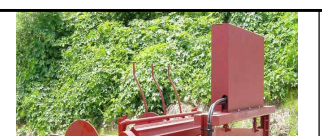 & ne \\
\hline \multirow{3}{*}{$\begin{array}{l}\text { Specifi- } \\
\text { cation }\end{array}$} & \multirow{2}{*}{$\begin{array}{l}\text { Unrolling } \\
\text { method }\end{array}$} & lower & $\begin{array}{l}\text { chain } 3,4 \text { lines, } \\
\text { lug height } 5 \mathrm{~cm}\end{array}$ & $\begin{array}{l}4 \text { lines, } \\
5 \mathrm{~cm}\end{array}$ & $\begin{array}{c}4 \text { lines, } \\
5 \mathrm{~cm}\end{array}$ \\
\hline & & upper & $\begin{array}{c}\text { Without the roller } \\
\text { drive }\end{array}$ & $\begin{array}{l}\text { With the roller drive } \\
\text { and guide }\end{array}$ & $\begin{array}{l}\text { With the upper belt } \\
\text { drive }\end{array}$ \\
\hline & \multicolumn{2}{|c|}{ Traverse angle } & $18^{\circ}$ & $15^{\circ}$ & $15^{\circ}$ \\
\hline \multirow{3}{*}{$\begin{array}{l}\text { Monito- } \\
\text { ring } \\
\text { results }\end{array}$} & \multicolumn{2}{|c|}{$\begin{array}{c}\text { Unrolling } \\
\text { with cutting bale }\end{array}$} & OK & OK & OK \\
\hline & \multicolumn{2}{|c|}{$\begin{array}{l}\text { Unrolling without } \\
\text { cutting bale }\end{array}$} & $\begin{array}{l}\text { *chain (3 lines) : N/A } \\
\text { *chain (4 lines) : OK }^{2}\end{array}$ & OK & OK \\
\hline & \multicolumn{2}{|c|}{ Residue treating } & N/A & $\mathrm{N} / \mathrm{A}$ & $\mathrm{OK}$ \\
\hline
\end{tabular}

회전식, 절단방식은 플라이 휠형, 배출은 상 부 배출방식으로 제작한 절단시험 장치를 이 용하여 Table 3 과 같이 절단 날 개수, 유입롤 러 및 절단드럼 회전수별로 요인시험결과 절 단날 개수는 많을수록 유입롤러 회전수는 적 을수록 절단정도는 양호한 경향을 보였으며, 절단칼날 개수 10 개, 유입롤러 회전수 280 $\mathrm{rpm}$, 절단날 회전수 $1,750 \mathrm{rpm}$ 에서 절단길이 $30 \mathrm{~mm}$ 이내비율 $89.3 \%$, 평균절단길이 13.7 $\mathrm{mm}$ 로 가장 양호한 것으로 나타났다. 그러나 순간적으로 많은 량이 유입되어 절단 후 배 출 시 상부 배출구 막힘이 없도록 개선이 요 구되었다.

연속작업이 가능토록 제작한 경사원통 해 머회전식 연화시험장치를 이용하여 Table 4와 같이 경사원통 각도별, 해머 회전수별로 요인 시험결과 연화정도는 경사원통각도가 $30^{\circ}$ 에
비해 $25^{\circ}$ 에서 양호하였으며, $20^{\circ}$ 에서는 경사 각도가 너무 낮아 세절물의 흐름이 원활하지 않았다. 해머 회전수는 $1,500 \mathrm{rpm}$ 에 비해 $1,300 \mathrm{rpm}$ 에서 양호하여, 경사원통각도 $25^{\circ}$, 해머 회전수 $1,300 \mathrm{rpm}$ 에서 절단길이 $30 \mathrm{~mm}$ 이내 비율 $91.4 \%$ 로 연화정도는 양호하였으 나, 투입구가 중앙에 위치해 있어 세절물 투 입 시 해머 회전에 의해 간섭을 받아 투입량 증대에 따른 성능향상을 기할 수 없어 개선 이 요구되었다.

3. 원형베일 세절시스템 시작기의 작업조 건 구명

설계요인 구명결과를 토대로 원형베일 해 체, 절단, 연화 일관 시스템 시작기를 설계 제작하여 시스템의 전·후 작업 연계성을 고

Table 3. Cutting posture by working conditions of cutting device.

\begin{tabular}{c|c|c|c|c|c|c|c|c}
\hline \multicolumn{3}{c|}{ Working condition } & \multicolumn{3}{c|}{ Cut length distribution (\%) } & Less than \\
\hline $\begin{array}{c}\text { Cutting } \\
\text { knifes } \\
\text { (ea) }\end{array}$ & $\begin{array}{c}\text { cutting } \\
\text { rotor speed } \\
\text { (rpm) }\end{array}$ & $\begin{array}{c}\text { Input roller } \\
\text { speed } \\
\text { (rpm) }\end{array}$ & $\begin{array}{c}\text { less } \\
10 \mathrm{~mm}\end{array}$ & $10 \sim 20 \mathrm{~mm}$ & $20 \sim 30 \mathrm{~mm}$ & $\begin{array}{c}\text { more than } \\
30 \mathrm{~mm} \\
\text { cut length } \\
(\mathrm{mm})\end{array}$ \\
\hline \hline 5 & 1,750 & 440 & 32.6 & 27.2 & 24.0 & 16.2 & 83.8 & 19.7 \\
\hline 5 & 1,750 & 280 & 27.6 & 31.7 & 21.5 & 19.2 & 80.8 & 19.9 \\
\hline 10 & 1,750 & 280 & 55.5 & 19.6 & 14.2 & 10.7 & 89.3 & 13.7 \\
\hline
\end{tabular}


Table 4. Softening posture by inclined cylinder angles and hammer speed of softening device.

\begin{tabular}{c|c|c|c|c|c|c}
\hline \multirow{2}{*}{$\begin{array}{c}\text { Angle of } \\
\text { inclined cylinder }\end{array}$} & $\begin{array}{c}\text { Hammer speed } \\
(\mathrm{rpm})\end{array}$ & \multicolumn{4}{|c|}{ Cut length distribution (\%) } & \multirow{2}{*}{$\begin{array}{c}\text { Less than 30 } \\
\text { mm (\%) }\end{array}$} \\
\cline { 3 - 7 } & less $10 \mathrm{~mm}$ & $\begin{array}{c}10 \sim 20 \\
\mathrm{~mm}\end{array}$ & $\begin{array}{c}20 \sim 30 \\
\mathrm{~mm}\end{array}$ & $\begin{array}{c}\text { more than } \\
\mathrm{mm}\end{array}$ & \begin{tabular}{c} 
(\%) \\
\hline \hline \multirow{2}{*}{$25^{\circ}$}
\end{tabular} \\
\cline { 2 - 7 } & 1,300 & 74.2 & 13.5 & 3.7 & 8.6 & 91.4 \\
\hline \multirow{2}{*}{$30^{\circ}$} & 1,500 & 64.1 & 12.1 & 6.5 & 17.3 & 82.7 \\
\cline { 2 - 7 } & 1,300 & 68.4 & 9.9 & 4.9 & 16.8 & 83.1 \\
\hline
\end{tabular}

려 마이크로프로세스 제어를 위해 필요한 작 업조건을 구명결과는 다음과 같다.

베일해체 작업조건 구명은 해체장치의 유 압펌프압력 $140 \mathrm{~kg} / \mathrm{cm}^{2}$ 로 조정한 상태에서 이 송 및 커팅작업을 on/off 스위치를 이용 수동 작동하면서 해체요인시험결과 Table 5와 같 이 커팅길이 $10 \mathrm{~cm}, 20 \mathrm{~cm}, 40 \mathrm{~cm}$ 별로 평균 사일리지 무게는 각각 $2.82 \mathrm{~kg}, 8.28 \mathrm{~kg}, 19.10$ $\mathrm{kg}$ 였으며, IRG 원형베일 $600 \mathrm{~kg}$ 기준 1 롤 해 체소요시간은 각각 106.4 분, 42 분, 23.6분으로 나타났다. 그러나 시험에서 on/off 스위치를 이용 수동 작동하던 것을 자동제어 시스템을 구축하여 연속작동하면 해체소요시간을 단축 할 수 있을 것으로 판단된다. 한편 해체 시 소요동력은 평균 $1.75 \mathrm{kw}$, 최대 $2.33 \mathrm{kw}$ 로 나 타났다.

절단작업조건 구명은 절단장치의 칼날개수
10 개, 절단날 회전수 $1,750 \mathrm{rpm}$, 유입롤러 회 전수 $280 \mathrm{rpm}$ 으로 맞춘 상태에서 해체장치에 의해 커팅된 사일리지 길이 $10 \mathrm{~cm}, 20 \mathrm{~cm}, 40$ $\mathrm{cm}$ 별로 절단장치에 투입하며 절단시험결과 Table 6과 같이 $30 \mathrm{~mm}$ 이내 비율은 각각 $85.7 \%, 94 \%, 97 \%$, 평균절단 길이는 $19.6 \mathrm{~mm}$, $12.8 \mathrm{~mm}, 10.3 \mathrm{~mm}$ 로 커팅된 사일리지 길이를 길게 하여 투입할수록 평균절단 길이는 짧아 지고, $30 \mathrm{~mm}$ 이내 비율은 높아 절단정도는 양호하게 나타났으며, 길이가 짧아짐에 따라 용적중은 각각 $95 \mathrm{~g} / \mathrm{L}, 118.7 \mathrm{~g} / \mathrm{L}, 130.3 \mathrm{~g} / \mathrm{L}$ 로 높게 나타났다. 베일 해체 시 커팅길이별 절 단기의 평균 소요동력은 Table 7과 같이 각 각 $1.03 \mathrm{kw}, 1.20 \mathrm{kw}, 1.46 \mathrm{kw}$ 로 커팅길이가 길을수록 증가하였다. 그러나 $40 \mathrm{~cm}$ 길이로 베일을 커팅하여 투입 시 평균 소요동력은 그다지 크지 않았으나, 순간 최대 소요동력

Table 5. Unrolling bale silage weight and time requirement by cutting bale silage lengths.

\begin{tabular}{c|c|c|c|c|c|c}
\hline $\begin{array}{c}\text { Cutting bale } \\
\text { silage length } \\
(\mathrm{cm})\end{array}$ & \multicolumn{2}{|c|}{$\begin{array}{c}\text { Unrolling bale silage } \\
\text { weight(kg/ time) }\end{array}$} & \multicolumn{2}{|c|}{ Unrolling time requirement } & \multicolumn{2}{c}{$\begin{array}{c}\text { Power requirement } \\
\text { (kw) }\end{array}$} \\
\cline { 2 - 7 } & Average & S.D & min/1 time & min/1 roll & Average & Max \\
\hline \hline 10 & 2.82 & 0.57 & 0.50 & 106.4 & & \\
\hline 20 & 8.28 & 0.92 & 0.58 & 42.0 & \multirow{2}{*}{1.75} & 2.33 \\
\hline 40 & 19.10 & 2.54 & 0.75 & 23.6 & & \\
\hline
\end{tabular}

Table 6 . Cutting accuracy by cutting bale silage lengths.

\begin{tabular}{|c|c|c|c|c|c|c|c|}
\hline \multirow{2}{*}{$\begin{array}{l}\text { Cutting bale } \\
\text { silage } \\
\text { length }(\mathrm{cm})\end{array}$} & \multicolumn{4}{|c|}{ Cut length distribution (\%) } & \multirow{2}{*}{$\begin{array}{c}\text { Less than } \\
30 \mathrm{~mm} \\
(\%)\end{array}$} & \multirow{2}{*}{$\begin{array}{l}\text { Average of } \\
\text { cut length } \\
(\mathrm{mm})\end{array}$} & \multirow{2}{*}{$\begin{array}{c}\text { Bulk } \\
\text { density } \\
(\mathrm{g} / \mathrm{L})\end{array}$} \\
\hline & less $10 \mathrm{~mm}$ & $10 \sim 20 \mathrm{~mm}$ & $20 \sim 30 \mathrm{~mm}$ & $\begin{array}{l}\text { more than } \\
30 \mathrm{~mm}\end{array}$ & & & \\
\hline 10 & $\overline{56.0}$ & 26.4 & 3.3 & 14.3 & 85.7 & 19.6 & 95.0 \\
\hline 20 & 67.7 & 24.0 & 2.3 & 6.0 & 94.0 & 12.8 & 118.7 \\
\hline 40 & 67.8 & 26.4 & 2.8 & 3.0 & 97.0 & 10.3 & 130.3 \\
\hline
\end{tabular}


Table 7. Cutting torque and power requirement by cutting bale silage lengths.

\begin{tabular}{c|c|c|c|c|c}
\hline \multirow{2}{*}{$\begin{array}{c}\text { Cutting bale } \\
\text { silage length (cm) }\end{array}$} & \multicolumn{2}{|c|}{ Torque (N.m) } & \multicolumn{2}{c|}{ Power requirement (kw) } & Working \\
\cline { 2 - 5 } possibility
\end{tabular}

※ Working possibility : $\bigcirc$ good , $\triangle$ overload, $\times$ bad.

Table 8. Softening accuracy by the amount of inputting cut silag.

\begin{tabular}{|c|c|c|c|c|c|c|}
\hline \multirow{2}{*}{$\begin{array}{l}\text { Input amount } \\
\text { of cut silage } \\
(\mathrm{kg} / \mathrm{h})\end{array}$} & \multirow{2}{*}{$\begin{array}{c}\text { Less than } \\
30 \mathrm{~mm} \\
(\%) \\
\end{array}$} & \multirow{2}{*}{$\begin{array}{c}\text { Average of } \\
\text { cut } \\
\text { length }(\mathrm{mm}) \\
\end{array}$} & \multirow{2}{*}{$\begin{array}{c}\text { Bulk density } \\
(\mathrm{g} / \mathrm{L})\end{array}$} & \multicolumn{2}{|c|}{$\begin{array}{c}\text { Power requirement } \\
(\mathrm{kw})\end{array}$} & \multirow{2}{*}{$\begin{array}{r}\text { Working } \\
\text { possibility }\end{array}$} \\
\hline & & & & Aver & Max & \\
\hline 500 & 96.7 & 10.1 & 83.5 & 0.81 & 0.83 & 0 \\
\hline 750 & 97.7 & 10.4 & 78.4 & 1.41 & 1.67 & 0 \\
\hline 1,000 & 92.3 & 11.1 & 82.2 & 2.01 & 2.60 & 0 \\
\hline 1,250 & 94.3 & 11.5 & 80.2 & 4.31 & 7.50 & $\triangle$ \\
\hline
\end{tabular}

이 $44.56 \mathrm{kw}$ 로 매우 높게 나타난 것은 해체 시 길게 커팅하여 투입하는 경우 투입량이 많아서 절단기에서 부하를 많이 받는 것으로 생각되었다. 따라서 절단정도와 소요동력 등 을 감안하여 베일해체 장치에서 $20 \mathrm{~cm}$ 내외 길이로 커팅하여 절단기에 투입 절단하는 것 이 좋을 것으로 판단되었다.

연화 작업조건 구명은 연화장치의 경사원 통각도 $25^{\circ}$, 해머날 회전수 $1,300 \mathrm{rpm}$ 로 맞춘 상태에서 Table 8과 같이 절단된 사일리지를 시간당 환산하여 $500 \mathrm{~kg}, 750 \mathrm{~kg}, 1,000 \mathrm{~kg}$, $1,250 \mathrm{~kg}$ 로 투입 시 $30 \mathrm{~mm}$ 이내 비율은 각각 $96.7 \%, 97.7 \%, 92.3 \%, 94.3 \%$ 였으며, 평균절단 길이는 $10.1 \mathrm{~mm}, 10.4 \mathrm{~mm}, 11.1 \mathrm{~mm}, 11.5$ $\mathrm{mm}$ 로 나타나 투입량이 많아질수록 평균절단 길이는 약간 길어지는 경향을 보였으나 큰 차이를 보이지는 않았으며, 용적중은 각각 $83.5 \mathrm{~g} / \mathrm{L}, 78.4 \mathrm{~g} / \mathrm{L}, 82.2 \mathrm{~g} / \mathrm{L}, 80.2 \mathrm{~g} / \mathrm{L}$ 로 나타났 다. 투입량별 평균 소요동력은 각각 $0.81 \mathrm{kw}$, $1.41 \mathrm{kw}, 2.01 \mathrm{kw}, 4.31 \mathrm{kw}$ 로 투입량이 증가할 수록 소요동력도 증가하는 경향을 보였으며, 투입량을 $1,250 \mathrm{~kg} / \mathrm{h}$ 로 투입시 평균 소요동력 은 그다지 크지 않았으나, 최대 소요동력이
$7.70 \mathrm{kw}$ 로 부하를 많이 받아 시간당 $1,000 \mathrm{~kg}$ 정도로 투입 연화하는 것이 좋을 것으로 판 단되었다. 한편, 연화정도를 알아보기 위해 작업가능성이 있는 범위에서 절단과 연화 후 용적중 변화를 비교분석한 결과 절단 후 $95.0 \sim 118.7 \mathrm{~g} / \mathrm{L}$ 에서 연화 후 $78.4 \sim 83.5 \mathrm{~g} / \mathrm{L}$ 로 용적중이 $17 \sim 30 \%$ 감소되어 해머 날의 타격 에 의해 팽연화 된 것으로 판단되었다.

\section{결 론}

양돈 급여에 적합한 원형베일 해체, 세절, 연화 일관시스템 개발을 위해 원형베일 사일 리지 종류별 물리적 특성을 분석하고, 요인 시험결과를 토대로 시작기를 설계 제작하여 기종별 작업조건 구명시험 결과는 다음과 같다.

원형베일 사일리지 종류별 물리적 특성에 있어 최대 절단력 및 최대절단력 까지 도달 거리는 IRG $133.88 \mathrm{~N}, 4.3 \mathrm{~mm}$, 볏짚 $46.65 \mathrm{~N}$, $6.03 \mathrm{~mm}$, 청보리 $36.3 \mathrm{~N}, 2.58 \mathrm{~mm}$ 로 나타났다.

원형베일 해체, 절단, 연화 요인시험결과 베일해체장치의 해체방식은 하부 체인컨베이 어 + 상부 벨트컨베이어식, 커팅방식은 상하 
구동 작두날식으로 한 경우 베일절단 유무에 관계없이 해체되며, 잔량처리가 되는 것으로 나타났다. 절단 요인시험결과 칼날 개수 10 개, 유입롤러 회전수 $280 \mathrm{rpm}$, 절단날 회전수 $1,750 \mathrm{rpm}$ 에서 절단정도는 양호하였으나 배출 구 개선이 요구되었다. 연화 요인시험결과 경사원통 각도 $25^{\circ}$, 햄머날 회전수 $1,300 \mathrm{rpm}$ 에서 연화정도는 양호하였으나 처리능률 향 상이 요구되었다.

설계요인 구명결과를 토대로 원형베일 해 체, 절단, 연화 일관작업이 가능하도록 시작 기를 설계제작 하여 작업조건 구명결과 해체 장치에서 해체와 동시에 $20 \mathrm{~cm}$ 길이로 커팅 하여 절단장치에 투입 시 평균 절단길이 $12.8 \mathrm{~mm}, 30 \mathrm{~mm}$ 이내 비율 $94 \%$ 로 절단정도 가 양호하였고 연속작업이 가능하였으며, 절 단된 사일리지 투입량별 연화시험결과 1,000 $\mathrm{kg} / \mathrm{h}$ 투입하여도 연화가 가능한 것으로 판단 되었다. 작업가능조건에서 각 장치의 평균 및 최대 소요동력을 측정해본 결과 해체장치 $1.75 \mathrm{kw}, 2.33 \mathrm{kw}$, 절단장치 $1.20 \mathrm{kw}, 18.82 \mathrm{kw}$, 연화장치 $2.01 \mathrm{kw}, 2.60 \mathrm{kw}$ 로 나타나, 시스템 현장설치 시 최대 소요동력을 고려 소요전력 산출이 필요한 것으로 판단되었다.

$$
\text { 사 사 }
$$

본 연구는 농촌진흥청 국립농업과학원 농업 과학기술 연구개발사업 (과제번호: PJ90702902) 의 지원에 의해 수행되었습니다.

\section{인 용 문 헌}

1. Cho, S.B., 2009. Making and using technology of winter barely silage for pigs. 2009 Annual Report of National Institute of Animal Science. Suwon, Korea, pp. 50-55.

2. Ha, Y.S., Park, K.K., Hong, D.H., Kim, J. G., Kwon, J. K., 2007. Development of round bale pre-processing system for TMR plants in order to increase the consumption of the domestic produced roughages ( I )Modeling of round bale pre-processing system for TMR plants. In: Proceedings of the KSAM 2007 Summer Conference. 12(2), 112-116.

3. Hong, D.H., Park, K.K., Ha, Y.S., Kim, H. J., Kim, B.K., 2005. Development of tractor attached roughage cut-feeder for round bale ( I )-Development of a cutting mechanism. In: Proceedings of the KSAM 2005 Summer Conference. 10(2), 74-79.

4. Hong, D.H., Park, K.K., Ha, Y.S., Kim, H. J., Kim, B.K., 2005. Development of tractor attached roughage cut-feeder for round bale (II)-Test of a tractor attached roughage cut-feeder for round bale. In: Proceedings of the KSAM 2005 Summer Conference. 10(2), 80-88.

5. Hong, D.H., Park, K.K., Ha, Y.S., Kim, H. J., Kim, B.K., 2005. Development of tractor attached roughage cut-feeder for round bale (III)-Cost analysis of a tractor attached roughage cut-feeder for round bale. In: Proceedings of the KSAM 2005 Summer Conference. 10(2), 89-94.

6. Park, K.K., Hong, D.H., Kim, H.J., Nah, K.D., 2000. Development of cuttingsoftening machine for improving the value of rice straw. In: Proceedings of the KSAM 2000 Winter Conference. 5(1), 120-128.

7. Yu, B.K., Oh, K.Y., Choi, G.J., Lee, S.H., Lee, K.H., 2002. Development of chopper for rice-straw round bale. In: Proceedings of the KSAM 2002 Winter Conference. 7(1), 248-253.

8. Zhang, M., Sword. M.L., Buckmaster. D.R., Cauffman. G.R., 2003. Design and evaluation of a corn silage harvester using shredding and flail cutting. Transactions of the ASAE. 46(6), 1503-1511. 